\title{
A Comparison of Ninth-Grade Students' States of Self-Esteem and Decision-Making with Respect to Their Levels of Physical Activity
}

\author{
Mümine Soytürk ${ }^{1} \&$ Özden Tepeköylü Öztürk ${ }^{2}$ \\ ${ }^{1}$ Department of Physical Education and Sports Teaching, Manisa Celal Bayar University, Manisa, Turkey \\ ${ }^{2}$ Department of Recreation, Pamukkale University, Denizli, Turkey \\ Correspondence: Özden Tepeköylü Öztürk, Department of Recreation, Pamukkale University, Denizli, Turkey.
}

Received: November 15, 2018

doi:10.5539/ies.v12n4p9

\author{
Accepted: December 30, 2018 \\ Online Published: March 10, 2019 \\ URL: https://doi.org/10.5539/ies.v12n4p9
}

\begin{abstract}
The aim of this study was to compare ninth-grade students' states of self-esteem and decision-making with regard to their levels of physical activity. A total of 374 students, of whom 205 were female and 169 were male $\left.\mathrm{x}_{(\mathrm{age})}=15.22 \pm 0.414\right)$, selected by convenience sampling from four different high schools determined by purposive sampling, participated voluntarily in the study. The research was designed in the general survey model as a causal-comparative study. In the study, the "Personal Decisiveness Scale" (PDS), "Self-Esteem Scale" (SES), "International Physical Activity Questionnaire" (IPAQ, short form) and Personal Information Form were used as data collection tools. In the data analysis, one-way ANOVA (Tukey), Kruskal-Wallis $\mathrm{H}$ test, $2 \times 3$ MANOVA and Pearson correlation analysis were used. Type 1 error was set to $5 \%(\alpha \leq 0.05)$. Exploratory indecisiveness and impetuous indecisiveness scores were found to be highly positively correlated, while both indecisiveness scores were found to be moderately positively correlated with self-respect. Regarding physical activity levels, levels of self-esteem among the Science High School students were found to be significantly higher in the HEPA (health-enhancing physical activity) group than in the inactive and minimally active groups. It was determined that students at the Social Sciences High School had lower self-esteem scores and higher impetuous indecisiveness scores than students from all the other high schools, and that they had higher exploratory indecisiveness scores than students from the Science High School. Students who engaged in regular physical activity had higher levels of self-esteem than those who did not, while females had higher levels of exploratory indecisiveness than males. Exploratory indecisiveness scores were found to be significantly lower among those who engaged in team sports compared to those who did individual sports. In conclusion, regarding the negative relationship between indecisiveness and self-esteem, it can be said that high levels of physical activity increase the self-esteem of students at higher academic levels, that students in Social Sciences High Schools need to be supported with more physical activity, and that females and those doing individual sports have higher levels of exploratory indecisiveness.
\end{abstract}

Keywords: physical activity level, High School student, self-esteem, indecisiveness, decision-making

\section{Introduction}

Nowadays, due to technological developments, transformations are taking place in several directions: digital games are replacing street games, TV screens are taking the place of books, and social media are replacing sports and arts. Besides children and young people who share less, who cannot show enough feeling and who tend to think less, this situation also results in inactivity. According to Brucher and Karateel (as cited in Çamliyer \& Çamliyer, 2018, p. 18), movement and being physically active is a key factor in an individual's development as a whole, and, moreover, in ensuring his/her social adaptation. In the first period of adolescence, defined as the high school stage (Başaran, 1974, p.39), it is known that in the movement-physical activity process, an individual's self-perception of his/her abilities stemming from his/her interaction with the environment has a dominant effect on his/her physically active behaviour later (Timo, Sami, Anthony, \& Jarmo, 2016). In another study, it was determined that the value given to physical activity by university students had a significant effect on their positive emotions (Yerlisu-Lapa \& Haş1-Korkmaz, 2017). One of the outcomes achieved by individuals who are physically active is the state of self-esteem for themselves. According to Rogers (as cited in Bogenç, 2005), self-esteem expresses the attitude that a person develops towards his/her self-concept and forms the affective aspect of his/her self-concept. Moreover, the analyses that a person makes related to him/herself are expressed by 
definitions such as self-esteem and self-respect. Kohut (1977) evaluated the self as "the core of the personality, the centre of perceptions and initiatives" (Terbaş, 2004).

Another concept with which self-concept is analyzed is the ego. This is defined as finding value in being loved and liked, and being satisfied with oneself (Yörükoğlu, 2007). When a person's self-esteem and ego-esteem are examined as integrative in the context of being an active individual, the environment of physical education and sports offers a number of opportunities as a self-assessment tool for developing self-esteem (Soytürk, Tepeköylü Öztürk, Topuz, \& Yetim, 2015).

Another important issue arises from the potential for an individual's self-esteem to affect the decisions that he/she makes (Beswick, Rothblum, \& Mann, 1988). As well as allowing the potential for self-esteem, the sporting environment can also activate the mechanisms for healthy decision-making. From the moment an individual encounters the concept of choice in life, he/she is in a position to make a decision. In this context, the chain of decisions an individual makes in the process directs his/her life. In terms of meaning, a decision is defined as "a definite judgement made by thinking about a task or a problem" (TLS, 2018). There are many factors affecting decision-making, and it is also possible to mention different decision-making styles. Decision-making styles in the fields of education and sport have been examined with regard to a number of variables (Temel, Birol, Akpınar, \& Nas, 2017; Kelecek, Altıntaş, \& Aşçı, 2013; Tekkurşun-Demir, Namlı, Hazar, Türkeli, \& Cicioğlu, 2018), yet very few studies have focused on indecisiveness (Sar1, 2007). In the findings of some of these, it has been determined that the concepts of self-esteem and problem-solving skills contribute significantly towards predicting the decision-making behaviours of high school students (Güçray, 2001). As another factor, decision-making and locus of control together are revealed as predictors of metacognitive functionality (Karsl1, 2015). It is argued that self-esteem in decision-making is higher in internally controlled high school students than in externally controlled high school students (Özcan-Candangil \& Ceyhan, 2006). Furthermore, decisiveness and problem-solving ability together are predictors of internal locus of control in adolescents (Çolakkadıŏlu \& Cenkseven-Önder, 2011). A state of indecision affects an individual's life as much as decisiveness does. Individuals take pains to establish a balance between decision and indecision under the effects of many stimulants in a globalized world. The indecisiveness that emerges with inability to make a decision is revealed in common speech as "even the worst decision is better than indecision". Therefore, since an examination of the triangle of indecisiveness, self-esteem and physical activity is considered valuable in terms of guiding adolescents towards a healthier lifestyle in terms of their adaptation and needs, the aim of this study is to compare ninth-grade students' states of self-esteem and decision-making with regard to their levels of physical activity.

\section{Method}

\subsection{Participants}

Students studying in ninth grade at an Anatolian High School, a Sports High School, a Social Sciences High School and a Science High School affiliated to Manisa Provincial Directorate of National Education participated in the study. In determining the schools, the purposive sampling technique was used, and for obtaining the data, an attempt was made to reach all ninth-grade students at these high schools with the convenience sampling method. On the day that the survey took place; the study was conducted with all willing students present at school. A total of 374 students, of whom 205 were female and 169 were male, took part in the study. The average age of the participants was $\mathrm{x}_{\text {(age) }}=15.22 \pm 0.414$. Their average height was recorded as $\mathrm{x}_{\text {(height) }}=168.95 \pm 7.887 \mathrm{~cm}$, while their average weight was recorded as $\mathrm{x}_{\text {(weight) }}=59.60 \pm 11.308 \mathrm{~kg}$. The distribution of the participants according to their physical activity level and gender with reference to the type of high school they attended is presented in Table 1.

Table 1. Distribution of ninth-grade students according to physical activity and gender with reference to type of high school attended

\begin{tabular}{|c|c|c|c|c|c|c|c|c|c|c|c|c|}
\hline \multirow[t]{2}{*}{ GROUP } & \multicolumn{2}{|c|}{ Inactive } & \multicolumn{2}{|c|}{$\begin{array}{c}\text { Minimally } \\
\text { Active }\end{array}$} & \multicolumn{2}{|c|}{ HEPA Active } & \multicolumn{2}{|c|}{ TOTAL } & \multicolumn{2}{|c|}{ Female } & \multicolumn{2}{|c|}{ Male } \\
\hline & $\mathrm{f}$ & $\%$ & $\mathrm{f}$ & $\%$ & $\mathrm{f}$ & $\%$ & $\mathrm{f}$ & $\%$ & $\mathrm{n}$ & $\%$ & $\mathrm{n}$ & $\%$ \\
\hline Science High School & 63 & 16.8 & 61 & 16.4 & 23 & 6.2 & 147 & 39.4 & 86 & 42.0 & 61 & 36.1 \\
\hline Social Sciences High School & 18 & 4.9 & 34 & 9.2 & 12 & 3.2 & 64 & 17.0 & 43 & 21.0 & 21 & 12.4 \\
\hline Anatolian High School & 30 & 8.0 & 55 & 14.8 & 34 & 9.2 & 119 & 31.8 & 62 & 30.2 & 57 & 33.7 \\
\hline Sports High School & 6 & 1.6 & 25 & 6.7 & 13 & 3.5 & 44 & 11.9 & 14 & 6.8 & 30 & 17.8 \\
\hline Total & 117 & 31.0 & 175 & 47.2 & 82 & 21.8 & 377 & 100.0 & 205 & 100.0 & 169 & 100.0 \\
\hline
\end{tabular}

HEPA $=$ Health-Enhancing Physical Activity 


\subsection{Measurement Tools Used}

With the aim of determining the students' physical activity levels, the "International Physical Activity Questionnaire" (IPAQ, short form) was used in the study. To determine their levels of indecisiveness, the "Personal Indecisiveness Scale" (PIS) was used, while the "Self-Esteem Scale" (SES) was used to reveal their levels of self-esteem. Moreover, a "Personal Information Form" was used to determine the independent variables.

\subsubsection{Personal Indecisiveness Scale (PIS)}

The Personal Indecisiveness Scale (PIS) developed by Bacanlı (1999) consists of 18 items. It is a five-point Likert-type scale and there are two independent subscales. The first subscale consists of 10 items, and since there are statements that include the inability to somehow make a definite decision despite exploring and examining a decision problem, it is named "exploratory indecisiveness". The second subscale consists of 8 items, and since it gathers together items including hasty decision-making and refraining from making a decision without exploring or examining a decision problem, it is named "impetuous indecisiveness". It was determined that the 18 items explained $43.04 \%$ of the total variance. In the reliability study of the PIS scale as a whole, the Cronbach alpha coefficient was calculated as .90 , while the test-retest stability coefficient was $r=.84$. For the "exploratory indecisiveness" subdimension, the Cronbach alpha coefficient was .88 , while the test-retest stability coefficient was determined as $r=.84$. For the "impetuous indecisiveness" subdimension, in the reliability study the Cronbach alpha coefficient was calculated as .85 , while the test-retest stability coefficient was $r=.78$. To prevent the responders from being affected by social desirability bias, it was suggested that the scale be named the "Personal Decisiveness Scale" (PDS) during implementations (Bacanl1, 1999), and this suggestion was adopted in the study. In this study, the Cronbach alpha coefficient was calculated as .920.

\subsubsection{Self-Esteem Scale (SES)}

The Self-Esteem Scale developed by Bogenç in 2005 consists of 20 items. It is in the form of a 5-point Likert-type scale. Responses to the items included in the scale are scored from "always" to "never". 15 of the items are arranged in a positive order, while the other 5 are arranged in a negative order. The lowest score that can be obtained from the scale is 20 , while the highest is 100 . The scale appears as one-dimensional. In the construct validity study, the factor loadings were found to be greater than .30 and to explain $36.3 \%$ of total variance. Internal consistency was determined as $\alpha=.81$ (Bogenç, 2005). For this study, the Cronbach alpha value was calculated as 0.830 .

\subsubsection{International Physical Activity Questionnaire (IPAQ, Short Form)}

The short form of the IPAQ was applied in our study. This questionnaire consists of 4 sections and 7 questions. The questionnaire contains questions related to periods of at least 10 minutes during the previous 7 days spent doing vigorous physical activity, moderate physical activity, walking, and sitting. To determine the levels of physical activity, the MET (metabolic equivalent of task) method was used. Based on the MET estimation, physical activities are classified in 3 categories: $<600 \mathrm{MET}-\mathrm{min} / \mathrm{wk}$ for inactive s, $>600-3000 \mathrm{MET}-\mathrm{min} / \mathrm{wk}$ for minimally active ones, and $>3000$ MET-min/wk for HEPA active ones (Arabacı \& Çankaya, 2007). Information was obtained individually from each subject, and weight and height measurements were made at the same time. The physical activity levels of the students were converted into independent variables as Inactive, Minimally Active and HEPA Active.

\subsection{Data Analysis}

In the data analysis, basic descriptive statistics such as percentages, means and standard deviation were used. For comparing the groups, t-test, one-way ANOVA (Tukey), 2x3 MANOVA and Kruskal-Wallis H test were used. For analysis of the relationships among the variables, Pearson correlation analysis was used. Type 1 error was set to $5 \%$. 
Table 2. Normal distribution fit for self-esteem, exploratory indecisiveness and impetuous indecisiveness scores of ninth-grade students

\begin{tabular}{|c|c|c|c|c|c|c|c|c|c|c|}
\hline & & \multirow{2}{*}{$\mathrm{n}$} & \multirow{2}{*}{ Minimum } & \multirow{2}{*}{ Maximum } & \multirow{2}{*}{$\bar{x}$} & \multirow{2}{*}{$\mathrm{sd}$} & \multicolumn{2}{|c|}{ Skewness } & \multicolumn{2}{|c|}{ Kurtosis } \\
\hline & & & & & & & St. & $\mathrm{sd}$ & St. & $\mathrm{sd}$ \\
\hline \multirow{3}{*}{$\begin{array}{l}\stackrel{0}{0} \\
\stackrel{\Xi}{\Xi}\end{array}$} & Self-Esteem & 115 & 38.00 & 100.00 & 78.3654 & 11.32629 & -.764 & .226 & 1.131 & .447 \\
\hline & Exploratory & 115 & 10.00 & 55.00 & 26.6273 & 9.99027 & .580 & .226 & .198 & .447 \\
\hline & Impetuous & 115 & 8.00 & 40.00 & 18.6083 & 7.32705 & .490 & .226 & -.267 & .447 \\
\hline \multirow{3}{*}{ 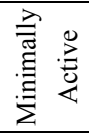 } & Self-Esteem & 175 & 45.00 & 111.00 & 78.5688 & 11.75048 & -.468 & .184 & .127 & .365 \\
\hline & Exploratory & 175 & 10.00 & 50.00 & 26.8287 & 9.80059 & .503 & .184 & -.126 & .365 \\
\hline & Impetuous & 175 & 8.00 & 40.00 & 18.9731 & 7.65564 & .762 & .184 & .056 & .365 \\
\hline \multirow{3}{*}{ 岕 } & Self-Esteem & 81 & 46.54 & 100.00 & 79.6287 & 12.62297 & -.725 & .267 & -.116 & .529 \\
\hline & Exploratory & 81 & 10.00 & 50.00 & 27.0126 & 8.83536 & .254 & .267 & -.105 & .529 \\
\hline & Impetuous & 81 & 8.00 & 36.00 & 18.8381 & 6.86452 & .441 & .267 & -.529 & .529 \\
\hline
\end{tabular}

\subsection{Research Design}

In the study, an attempt was made to reveal the states of self-esteem and decisiveness of ninth-grade students according to their levels of physical activity with the causal-comparative type of general survey model. In a causal-comparative study, the researchers attempt to determine the reasons for or results of differences that already exist among individuals or groups (Fraenkel, Wallen, \& Hyun, 2017, pp. 366-367). Therefore, the group variables of gender, education at different types of school, physical activity level and physical activity type were used as independent variables for causality and comparison. As dependent variables, the states of self-esteem and decision-making (indecisiveness) were examined. It was aimed to reveal which of the independent variables resulted in the creation of high self-esteem and low indecisiveness. When considered from the viewpoint of comparison of the groups, each group's making a choice of high school a short time before and being appointed to high schools with different structures from each other were determined to be important.

\section{Findings}

Table 3. Relationship of ninth-grade students' self-esteem, exploratory indecisiveness and impetuous indecisiveness with their physical activity levels (PAL)

\begin{tabular}{lcccc}
\hline & $\begin{array}{c}\text { Exploratory } \\
\text { Indecisiveness }\end{array}$ & $\begin{array}{c}\text { Impetuous } \\
\text { Indecisiveness }\end{array}$ & Self-Esteem & Total PAL Score \\
\hline Impetuous Indecisiveness & 1 & & & \\
Exploratory Indecisiveness & $.714^{* *}$ & 1 & 1 & 1 \\
Self-Esteem & $-.339^{* *}$ & $-.342^{* *}$ & -.096 & \\
Total PAL Score & .039 & .033 & & \\
\hline
\end{tabular}

$* * \mathrm{p}<.01$ (2-tailed).

The Pearson correlation analysis, performed to establish whether there were significant relationships among self-esteem, exploratory indecisiveness, impetuous indecisiveness and PAL scores, revealed a highly positive, significant relationship between exploratory indecisiveness and impetuous indecisiveness $(\mathrm{r}=.714, \mathrm{p}<.01)$. Impetuous indecisiveness was found to be moderately negatively correlated with self-esteem $(r=-.339, p<.01)$. Similarly, exploratory indecisiveness and self-esteem were determined to be moderately negatively correlated $(\mathrm{r}=-.342, \mathrm{p}<.01)$. No significant relationships were found between physical activity levels and self-esteem, exploratory indecisiveness or impetuous indecisiveness ( $p>05)$. 
Table 4. Comparison of Self-esteem and indecisiveness levels of ninth-grade students with their physical activity levels with regard to type of school attended

\begin{tabular}{|c|c|c|c|c|c|c|c|}
\hline School Type & & Physical Activity Level & $\mathrm{n}$ & Mean Rank & df & $x^{2}$ & $\mathrm{p}$ \\
\hline \multirow{9}{*}{ Science High School } & \multirow{3}{*}{ Self-Esteem } & Inactive & 63 & 69.54 & \multirow{3}{*}{2} & \multirow{3}{*}{6.866} & \multirow{3}{*}{$0.032 *$} \\
\hline & & Minimally Active & 61 & 70.57 & & & \\
\hline & & HEPA Active & 23 & 95.33 & & & \\
\hline & \multirow{3}{*}{ Exploratory Indecisiveness } & Inactive & 63 & 70.65 & \multirow{3}{*}{2} & \multirow{3}{*}{2.764} & \multirow{3}{*}{.251} \\
\hline & & Minimally Active & 61 & 80.62 & & & \\
\hline & & HEPA Active & 23 & 65.61 & & & \\
\hline & \multirow{3}{*}{ Impetuous Indecisiveness } & Inactive & 63 & 71.37 & \multirow{3}{*}{2} & \multirow{3}{*}{1.009} & \multirow{3}{*}{.604} \\
\hline & & Minimally Active & 61 & 78.16 & & & \\
\hline & & HEPA Active & 23 & 70.20 & & & \\
\hline
\end{tabular}

$* \mathrm{p}<0.05$.

As a result of the Kruskal-Wallis $\mathrm{H}$ test performed to determine whether or not the ninth-grade students' self-esteem, exploratory indecisiveness and impetuous indecisiveness scores differed according to their levels of physical activity at the high schools they attended, the self-esteem scores of the HEPA group at the Science High School were found to be statistically significantly higher than those of the inactive and minimally active groups $\left[\mathrm{x}^{2}\right.$ $(\mathrm{sd}=2, \mathrm{n}=374)=6.866, \mathrm{p}<.05]$. Neither the self-esteem scores of students at the Social Sciences, Anatolian and Sports High Schools nor the exploratory and impetuous indecisiveness scores of students at any of the high schools were affected by their levels of physical activity ( $\mathrm{p}>.05)$.

Table 5. One-Way ANOVA comparison of ninth-grade students' levels of self-esteem and indecisiveness with regard to the school type variable

\begin{tabular}{|c|c|c|c|c|c|c|c|c|c|c|c|}
\hline & $\begin{array}{c}\text { High School } \\
\text { Type }\end{array}$ & $\mathrm{n}$ & $\bar{x}$ & $\mathrm{sd}$ & $\begin{array}{l}\text { Source of } \\
\text { Variance }\end{array}$ & $\begin{array}{c}\text { Total } \\
\text { Squares }\end{array}$ & $\mathrm{df}$ & $\begin{array}{c}\text { Mean } \\
\text { Squares }\end{array}$ & $\mathrm{F}$ & $\mathrm{p}$ & $\begin{array}{l}\text { Significant } \\
\text { Difference }\end{array}$ \\
\hline \multirow{4}{*}{ 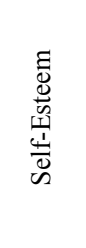 } & Science & 147 & 82.09 & 11.249 & $\begin{array}{l}\text { Between } \\
\text { Groups }\end{array}$ & 7489.779 & 3 & 2496.593 & \multirow{4}{*}{18.088} & \multirow{4}{*}{$0.001 *$} & \multirow{4}{*}{$1,3,4-2$} \\
\hline & $\begin{array}{c}\text { Social } \\
\text { Sciences }\end{array}$ & 64 & 69.85 & 13.542 & $\begin{array}{l}\text { Within } \\
\text { Groups }\end{array}$ & 51070.247 & 370 & 138.028 & & & \\
\hline & Anatolian & 119 & 77.59 & 12.040 & Total & 58560.027 & 373 & & & & \\
\hline & Sports & 44 & 82.50 & 9.564 & & & & & & & \\
\hline \multirow{4}{*}{ 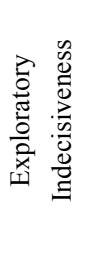 } & Science & 147 & 24.77 & 9.266 & $\begin{array}{l}\text { Between } \\
\text { Groups }\end{array}$ & 1311.799 & 3 & 437.266 & \multirow{4}{*}{4.853} & \multirow{3}{*}{$0.003 *$} & \multirow{3}{*}{$2-1$} \\
\hline & $\begin{array}{c}\text { Social } \\
\text { Sciences }\end{array}$ & 64 & 29.78 & 11.131 & $\begin{array}{l}\text { Within } \\
\text { Groups }\end{array}$ & 33336.169 & 370 & 90.098 & & & \\
\hline & Anatolian & 119 & 27.79 & 9.390 & Total & 34647.969 & 373 & & & & \\
\hline & Sports & 44 & 26.09 & 7.756 & & & & & & & \multirow{5}{*}{$2-1,3,4$} \\
\hline \multirow{4}{*}{ 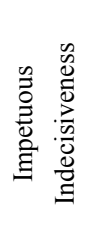 } & Science & 147 & 16.86 & 5.868 & $\begin{array}{l}\text { Between } \\
\text { Groups }\end{array}$ & 1524.352 & 3 & 508.117 & \multirow{4}{*}{10.034} & \multirow{4}{*}{$0.000^{*}$} & \\
\hline & $\begin{array}{c}\text { Social } \\
\text { Sciences }\end{array}$ & 64 & 22.57 & 8.444 & $\begin{array}{l}\text { Within } \\
\text { Groups }\end{array}$ & 18735.937 & 370 & 50.638 & & & \\
\hline & Anatolian & 119 & 19.42 & 7.813 & Total & 20260.289 & 373 & & & & \\
\hline & Sports & 44 & 18.16 & 6.839 & & & & & & & \\
\hline
\end{tabular}

$* \mathrm{p}<0.05$.

The single-factor ANOVA, performed in order to establish whether or not the ninth-grade students' self-esteem, exploratory indecisiveness and impetuous indecisiveness scores differed according to the type of school they attended, revealed that self-esteem scores of students at the Social Sciences High School were lower than those of students at the other types of high school $\left(\mathrm{F}_{(3,370)}=18.088, \mathrm{p}<.05\right)$. Moreover, exploratory indecisiveness scores of Social Sciences High School students were found to be significantly higher than those of Science High School students $\left(\mathrm{F}_{(3,370)}=4.853, \mathrm{p}<.05\right)$. In addition, impetuous indecisiveness scores of Social Sciences High School students were found to be significantly higher than those of students at all the other high schools $\left(\mathrm{F}_{(3,370)}=10.034\right.$, 
$\mathrm{p}<.05)$.

Table 6. Comparison of ninth-grade students' levels of self-esteem and indecisiveness according to gender and level of regular physical activity (RPA)

\begin{tabular}{lccccccc}
\hline Source of Variance & Dependent Variable & Sum of Squares & df & Mean Square & F & p & $\eta^{2}$ \\
\hline \multirow{4}{*}{ Gender } & Self-Esteem & 12.260 & 1 & 12.260 & .080 & .777 & .000 \\
& Exploratory Indecisiveness & 657,552 & 1 & 657.553 & 7.262 & .007 & .019 \\
& Impetuous Indecisiveness & 53.903 & 1 & 53.903 & .992 & .320 & .003 \\
RPA & Self-Esteem & 1397.487 & 1 & 1397.487 & 9.137 & .003 & .024 \\
& Exploratory Indecisiveness & 194.109 & 1 & 194.109 & 2.144 & .144 & .006 \\
& Impetuous Indecisiveness & 117.652 & 1 & 117.652 & 2.166 & .142 & .006 \\
Gender*RPA & Self-Esteem & 344.554 & 1 & 344.554 & 2.253 & .134 & .006 \\
& Exploratory Indecisiveness & 75.668 & 1 & 75.668 & .836 & .361 & .002 \\
& Impetuous Indecisiveness & 32.820 & 1 & 32.820 & .604 & .438 & .002 \\
Error & Self-Esteem & 56592.924 & 370 & 152.954 & & & \\
& Exploratory Indecisiveness & 33502.014 & 370 & 90.546 & & & \\
Total & Impetuous Indecisiveness & 20101.231 & 370 & 54.328 & & & \\
& Self-Esteem & 2370230.848 & 374 & & & & \\
& Exploratory Indecisiveness & 302197.806 & 374 & & & \\
\end{tabular}

$* \mathrm{p}<0.05$.

When the analysis results (2x3 MANOVA) were evaluated, it was seen that the gender*regular physical activity interaction did not significantly differ in the self-esteem or indecisiveness variables, whereas the basic effects of gender (Pillai's Trace $=.066, \mathrm{~F}=8.725, \mathrm{p}=.000$ ) and of regular physical activity (Pillai's Trace $=.025 ; \mathrm{F}=3.115$; $\mathrm{p}=.026$ ) were significant. To determine which independent variable contributed to multivariate significance in which dependent variable, the ANOVA test was performed. Accordingly, self-esteem levels of students engaging in regular physical activity $(X=80.66)$ were higher than those of students not engaging in regular physical activity $(X=76.67)$, while exploratory indecisiveness levels of females $(X=28.124)$ were higher than those of males $(\mathrm{X}=25.385)$.

Table 7. Comparison of ninth-grade students' levels of self-esteem and indecisiveness according to type of sport played

\begin{tabular}{|c|c|c|c|c|c|c|c|c|c|c|c|}
\hline & Group & $\mathrm{N}$ & $\bar{x}$ & sd & $\begin{array}{l}\text { Source of } \\
\text { Variance }\end{array}$ & $\begin{array}{c}\text { Total } \\
\text { Squares }\end{array}$ & $\mathrm{df}$ & $\begin{array}{c}\text { Mean } \\
\text { Squares } \\
\end{array}$ & F & $\mathrm{p}$ & $\begin{array}{l}\text { Significant } \\
\text { Difference }\end{array}$ \\
\hline \multirow{3}{*}{ 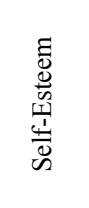 } & $\begin{array}{c}\text { No Physical } \\
\text { Activity }\end{array}$ & 119 & 77.42 & 13.247 & $\begin{array}{l}\text { Between } \\
\text { Groups }\end{array}$ & 615.011 & 2 & 307.505 & \multirow{3}{*}{1.969} & \multirow{3}{*}{0.141} & \multirow{3}{*}{-} \\
\hline & $\begin{array}{c}\text { Individual } \\
\text { Sports }\end{array}$ & 148 & 78.15 & 13.092 & $\begin{array}{l}\text { Within } \\
\text { Groups }\end{array}$ & 57945.016 & 371 & 156.186 & & & \\
\hline & Team Sports & 107 & 80.58 & 10.657 & Total & 58560.027 & 373 & & & & \\
\hline \multirow{3}{*}{ 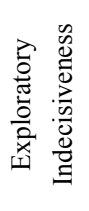 } & $\begin{array}{c}\text { No Physical } \\
\text { Activity }\end{array}$ & 119 & 25.36 & 9.248 & $\begin{array}{l}\text { Between } \\
\text { Groups }\end{array}$ & 1705.667 & 2 & 852.833 & \multirow{3}{*}{9.605} & \multirow{3}{*}{$0.001 *$} & \multirow{3}{*}{2,3} \\
\hline & $\begin{array}{c}\text { Individual } \\
\text { Sports }\end{array}$ & 148 & 29.36 & 10.502 & $\begin{array}{l}\text { Within } \\
\text { Groups }\end{array}$ & 32942.302 & 371 & 88.793 & & & \\
\hline & Team Sports & 107 & 24.66 & 7.910 & Total & 34647.969 & 373 & & & & \\
\hline \multirow{3}{*}{ 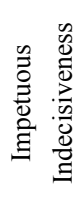 } & $\begin{array}{c}\text { No Physical } \\
\text { Activity }\end{array}$ & 119 & 18.26 & 6.657 & $\begin{array}{l}\text { Between } \\
\text { Groups }\end{array}$ & 204.920 & 2 & 102.460 & \multirow{3}{*}{1.895} & \multirow{3}{*}{.152} & \multirow{3}{*}{-} \\
\hline & $\begin{array}{l}\text { Individual } \\
\text { Sports }\end{array}$ & 148 & 19.72 & 8.147 & $\begin{array}{l}\text { Within } \\
\text { Groups }\end{array}$ & 20055.369 & 371 & 54.058 & & & \\
\hline & Team Sports & 107 & 18.15 & 6.913 & Total & 20260.289 & 373 & & & & \\
\hline
\end{tabular}

$* \mathrm{p}<0.05$.

As a result of the single-factor ANOVA performed to determine whether or not the ninth-grade students' 
self-esteem, exploratory indecisiveness and impetuous indecisiveness scores differed according to the type of sports they played, it was seen that exploratory indecisiveness scores of students engaging in team sports were significantly lower than those of students engaging in individual sports $\left(\mathrm{F}_{(3,370)}=9.605, \mathrm{p}<.05\right)$.

\section{Discussion and Conclusion}

In this study, self-esteem and exploratory and impetuous indecisiveness in ninth-grade students were examined with regard to their levels of physical activity. The first prediction was established on the assumption that exploratory and impetuous indecisiveness scores would be significantly and inversely correlated with self-esteem levels. The research findings are such as to confirm this hypothesis. The present negative relationship was determined as moderate by Büyüköztürk (2011). The findings of the study conducted by Sarı (2007) with university students show similarity with the current study findings (Sar1, 2007). Similarly, significant negative relationships were found between self-esteem scores of males who did not engage in sport and their scores for social acceptance, athletic ability, physical appearance, behavior, close friendship and global self-esteem (Yegül, 1999). From a different viewpoint, this finding is supported by Güçray's study, in which it was revealed that there were significant positive relationships between decision-making behaviors and self-esteem scores (Güçray, 2001).

Another prediction, namely the expectation that young people who were physically active but who were also attending schools with a better-quality academic level than others would have higher levels of self-esteem, is supported by the findings obtained in the study. The fact that self-esteem in students in the HEPA active group at the Science High School was found to be higher may be due to the fact that being physically active created a favorable situation. In a study conducted with high school students, Ürün (2010) found a significant difference in participants' levels of self-esteem according to the types of school they attended. It was concluded that self-esteem scores were highest in students at general high schools and lowest in students at vocational high schools (Ürün, 2010). Although levels of physical activity were not discussed in that study, differences on an academic basis were still revealed in the anticipated way. In another study, self-respect scores in choice of school type were found to be higher in private school students, and in decisions with a negative decision-making structure, significant differences were revealed with regard to possession of unsuitable decision-making styles such as indifference to stress, hyperarousal and avoidance (Güçray, 2003). Starting from this point of view, it can be said that the type of school had an effect on self-esteem in terms of its academic quality, but that when physical activity was at the HEPA level, a more significant difference in level of self-esteem was created. In relation to this, among all participants, the lowest self-esteem scores were found in students at the Social Sciences High School. Moreover, students at the same school had higher exploratory indecisiveness scores than students at the Science High School and higher impetuous indecisiveness scores than students at all the other high schools. This situation reveals that Social Sciences High School students are in need of support with regard to self-esteem and indecisiveness by being encouraged to engage in physical activities. In another study, contrary to the findings of our study, no significant differences were found in the self-esteem levels of students at Science and Social Sciences High Schools (Birol \& Yazic1, 2011). Since the Social Sciences High Schools were established in 2003, studies conducted on this type of school in this sense limit the ability to make comparisons. For example, in one study in which this school type is included among the specified schools and which deals with school burnout, scores of students at Social Sciences High School did not differ from those of students at Science, Anatolian and Vocational High Schools with respect to several variables (Seçer \& Gençdoğan, 2014); however, this finding cannot be attributed to self-esteem and indecisiveness levels. Moreover, in a study conducted in high schools in the relatively old system, in the comparison made with regard to decision-making styles, it was determined that students attending General High Schools used ineffective decision-making styles more frequently than students at Anatolian and Private High Schools (Güçray, 2001).

The third prediction of the study was established on the assumption that adolescents and youths who engaged in sports or who were physically active would have higher levels of self-esteem. Based on this prediction, the findings obtained in this study are frequently supported in the field literature (Karakaya, Coşkun, \& Ağaoğlu, 2006; Erşan, Doğan, \& Doğan, 2009; Hawker, 2012; Soytürk et al., 2015; Timo et al., 2016). Adolescents, particularly in this period, enjoy being able to succeed in a new and difficult task, to act with freedom and to see the product of their efforts (Çamlıyer \& Çamliyer, 2018, p. 44), and sporting environments offer them opportunities in this regard and can contribute to their self-development.

It was also expected that the gender variable would affect the independent variables together with regular physical activity, yet only the exploratory indecisiveness levels of females were concluded to be higher and more significant than those of males. Accordingly, females experience the problem of "inability to somehow make a definite decision despite exploring and examining a decision problem" (Bacanl, 1999). Again, in Sarı's (2007) study, exploratory indecisiveness levels of females were found to be higher than those of males. Güçray (2001) 
concluded that compared with male adolescents, female adolescents experienced more stress than males in decision-making situations. With regard to decision-making styles, in a study made with athletes, however, significant differences were not obtained according to the gender factor (Kelecek et al., 2013). Again, it was reported that those engaging in sport used a careful decision-making style in decision-making significantly more effectively than those not engaging in sport (Birol \& İnce, 2016).

In the present study, it was found that exploratory indecisiveness levels in students who took part in team sports were lower than in those who engaged in individual sports. This situation can be said to be due to the fact that as a consequence of performing duties together as part of a team, the strength and confidence that result from cooperation are effective for making definite decisions during the decision-making process. In another study, it was revealed that team sport athletes had significantly higher levels of self-esteem and careful behaviour regarding decision-making styles than athletes who did individual sports, while those who took part in individual sports displayed avoidant attitudes when making decisions and experienced panic in decision-making when compared to those who played team sports (Birol \& İnce, 2016). In another study dealing with the sports type variable, however, no significant difference was obtained between team and individual athletes with regard to decision-making styles (Tekkurşun-Demir et al., 2018). As a result, this study shows that increasing the level of physical activity, increases self-esteem and decreases indecision. In the light of this view, active participation of adolescents in sports should be encouraged.

\section{Recommendations}

The importance of increasing self-esteem for decreasing indecisiveness has been clearly revealed. Based on findings in the study and in the literature, it is recommended that all children and young people engage in physical activities to support their feelings of self-esteem. The fact that Social Science High School students' levels of self-esteem were found to be lower and that their levels of indecisiveness were found to be higher than those of other high school students can be said to reveal the importance of increasing support for physical activities and, perhaps, the necessity of varying them. Furthermore, according to the study findings, participation in team sports at this development level and in this age group is recommended.

\section{References}

Arabacı, R., \& Çankaya, C. (2007). Physical activity level of physical education teachers. Journal of Faculty of Education, 20, 1-15.

Bacanl, F. (1999). The development of indeciveness scale. Turkish Psychological Counseling and Guidance Journal (Vol. II). Retrieved from https://toad.edam.com.tr/sites/default/files/pdf/kararsizlik-olcegi-toad.pdf

Başaran, İ. E. (1974). Eğitim psikolojisi (4. ed). Ankara: Yargıçoğlu

Beswick, G., Rothblum, E. D., \& Mann, L. (1988). Psychological antecedents of student procrastination. Australian Psychologist, 23(2), 207-217. https://doi.org/10.1080/00050068808255605

Birol, S. Ş., \& İnce, A. (2016). Determination of self-esteem in decision making and decision making styles of the students participating in sportive recreational activities. International Journal of Anatolia Sport Sciences, 1(1), 68-68. https://doi.org/10.22326/ijass.6

Birol, Z. N., \& Yazıc1, H. (2011). Perfectionism, self esteem and leadership in science and social sciences high school gifted students. KARADENIZ (Black Sea-Черное Mope), 3(12), 113-122. Retrieved from http://dergipark.gov.tr/download/article-file/155363

Bogenç, A. (2005). Self-esteem scala. In Y. Kuzgun \& F. Bacanlı (Eds.), Scales used in psychological counseling and guidance (2nd ed., pp. 141-152). Ankara: Nobel.

Büyüköztürk, Ş. (2011). Sosyal bilimler için veri analizi el kitabi - istatistik, araştirma deseni, SPSS uygulamalari ve yorum (15. Baskı). Ankara: Pegem A Yayınc1lı.

Çamlıyer, H., \& Çamliyer, H. (2018). Eğitim bütünlüğü içinde çocuk hareket eğitimi ve oyun (8. Ed.). Manisa: Manisa Celal Bayar University.

Çolakkadıoğlu, O., \& Cenkseven-Önder, F. (2011). The Role of Decision Making And Problem Solving in Predicting Locus of Control Among Adolescents. Çukurova University Journal of Social Sciences, 20(2), 317-330.

Erşan, E. E., Doğan, O., \& Doğan, S. (2009). The relationship between self-esteem levels and some sociodemographic characteristics of the students of college of physical education and sports. Clinical Psychiatry, 12(1), 35-42. Retrieved from https://www.journalagent.com/kpd/pdfs/KPD_12_1_35_42.pdf 
Fraenkel, J. R., Wallen, N. E., \& Hyun, H. H. (2017). How to design and evaluate research in education. McGrawHill (8th ed., Vol. 91). New York: McGraw-Hill.

Güçray, S. (2001). The relationship between decision making behavior and self-respect and problem solving skills in adolescents. Çukurova University Journal of Social Sciences, 8, 106-121.

Güçray, S. S. (2003). The analysis of decision making behaviors and perceived problem solving skills in adolescents. The Turkish Online Journal of Educational Technology - TOJET, 2(5), 1303-6521.

Hawker, C. L. (2012). Physical activity and mental well-being in student nurses. Nurse Education Today, 32, 325-331. https://doi.org/10.1016/j.nedt.2011.07.013

Karakaya, I., Coşkun, A., \& Ağaoğlu, B. (2006). Evaluation of depression, anxiety and self-esteem levels in swimmers. Anatolian Journal of Psychiatry, 7(3), 162-166. Retrieved from http://search.ebscohost.com/login.aspx?direct=true \&db=psyh\&AN=2006-12781-005\&site=ehost-live\%0Ah ttp://karakaya73@yahoo.com

Karsli, T. A. (2015). The relation among metacogitive functions, decision making and locus of control in young adolescents at primary school. Electronic Journal of Social Sciences, 14(55), 16-31. Retrieved from http://www.esosder.org

Kelecek, S., Altıntaş, A., \& Aşçı, F. H. (2013). Determinations of athletes' decision-making styles. CBU Journal of Physical Education and Sport Sciences Sporculartn, 8(1), 21-27. Retrieved from http://dergipark.gov.tr/download/article-file/370598

Özcan-Candangil, S., \& Aydoğan, A. C. (2006). Decisional self-esteem and stress levels of high school students with different locus of controls according to some personal variables. Journal of Social Sciences, 2(1), 71-88.

Sar1, E. (2007). The effects on the self-esteem levels of aggressive, investigator and general indecisiveness forms of Turkish University students. Educational Sciences in Theory and Practice, 7(2), 897-926.

Seçer, İ., \& Gençdoğan, B. (2014). The evaluation of school burnout in terms of various variables in secondary school students. Turkish Journal Of Education, 3(3), 4-10. https://doi.org/10.19128/turje.48236

Soytürk, M., Tepeköylü Öztürk, Ö., Topuz, E., \& Yetim, H. (2015). The investigation of the relationship between self esteem and attitudes towards cheating of the physical education and sports prospective teachers' (CBU, PES Teachers'). International Journal of Sport, Exercise \& Training Science, 1(1), 20-30. https://doi.org/10.18826/ijsets.75041

Tekkurşun-Demir, G., Namlı, S., Hazar, Z., Türkeli, A., \& Cicioğlu, H. İ. (2018). Investigation of individual and team athletes' decision making styles and the level of mental well-being. CBU J Phys Edu Sport Sci, 13(1), 176-191. Retrieved from http://dergipark.gov.tr/download/article-file/499661

Temel, V., Birol, S. S.., Akpınar, S., \& Nas, K. (2017). Determınation of the traid anger and anger expression styles and decision-makıng levels of the students. The Journal of International Anatolia Sport Science, (3), 122-132. Retrieved from https://www.journalagent.com/jiasscience/pdfs/JIASS-98608-ORIGINAL_ RESEARCH-TEMEL.pdf

Terbaş, O. (2004). Disorders of the self according to self- psychological theory: A case presentation. Turkish Journal of Psychiatry, 15(1), 70-76.

Timo, J., Sami, Y. P., Anthony, W., \& Jarmo, L. (2016). Perceived physical competence towards physical activity, and motivation and enjoyment in physical education as longitudinal predictors of adolescents' self-reported physical activity. Journal of Science and Medicine in Sport, 19(9), 750-754. https://doi.org/10.1016/j.jsams.2015.11.003

TLS. (2018). Turkish Language Society. Retrieved from http://www.tdk.gov.tr/

Ürün, A. E. (2010). The relatıonship between the self-esteem level and the vocational maturtty of high school studens (Unpublished master's thesis) Balıkesir Üniversitesi. Balıkesir, Turkey https://doi.org/10.1186/s12934-017-0832-4

Yegül, I. B. (1999). Comparison of self-esteem and athletic proficiency scores of non-athletic boys and athletes. (Unpublished master's thesis). Hacettepe University, Ankara, Turkey.

Yerlisu-Lapa, T., \& Haş1-Korkmaz, N. (2017). Effect of physical activity levels on negative and positive affect comparison to the gender: Sample of Akdeniz and Uludağ Universities. Journal of Human Sciences, 14(4), 
3177. https://doi.org/10.14687/jhs.v14i4.4478

Yörükoğlu, A. (2007). Gençlik çă̆ı. İstanbul: Özgür Yayınları.

\section{Copyrights}

Copyright for this article is retained by the author(s), with first publication rights granted to the journal.

This is an open-access article distributed under the terms and conditions of the Creative Commons Attribution license (http://creativecommons.org/licenses/by/4.0/). 